Received: 15 Febuary 2020

Accepted: 16 April 2020

Online: 5 May 2020

Authors:

S. Saini $₫$

Department of Agriculture, Roorkee College,

Roorkee, Uttarakhand

K. K. Saini

Agriculture Consultant, Himgiri Krishi Vikas

Gramodhyog Sansthan, Haridwar, Uttarakhad

$\bigotimes$ shilpasaini654321@gmail.com

Emer Life Sci Res (2020) 6(1): 28-33

E-ISSN: 2395-6658

P-ISSN: 2395-664X

DOI: https://doi.org/10.31783/elsr.2020.612833

\section{Review Article \\ Chenopodium album Linn: An outlook on weed cum nutritional vegetable along with medicinal properties}

\author{
Shilpa Saini, Kamal Kant Saini
}

\begin{abstract}
The Chenopodium album is a significant nutritious and medicinally beneficial plant. Its fresh leaves and stem are full of nutrients, especially amino acids. The leaves of $C$. album contain various nutrients such as protein, fat, fiber, minerals and vitamins. Moreover, it is also a good source of iron and calcium. Chenopodium album has many medicinal properties such as antimicrobial, antihelmintic, antioxidant, antidiarrheal, and hepato-protective. The leaves of this plant are used in traditional medicines to treat digestive, peptic ulcer and hepatic disorder. Therefore, the Chenopodium album is a beneficial plant for human beings. However, limited research studies have been conducted by researchers for the processing of this plant. This article mainly discusses different aspects of this plant to enhance the awareness on its nutritional significance.
\end{abstract}

Keywords bathua, Chenopodium album, health benefits, medicinal properties, nutritional composition, phytochemicals

\section{Introduction}

Chenopodium album Linn is originating from Western Asia and belongs to the family "Chenopodiaceae". This plant is categorized under the genus "Chenopodium" which is widely distributed all over the world and has about 250 species [1]. It is found throughout the world mainly in India, North America, Northern East and Europe [2]. Generally, about 21 species of $C$. album are found in India mainly in Rajasthan, Himachal, Uttarakhand and Uttar Pradesh [3-4], where some species are cultivated as vegetables and some are grown as a grain crop (Chenopodium quinoa and C. album) [5-6]. C. album has been renewed in Asia in the present time as a valuable food source because of its versatility and its potential to grow under stressed conditions such as low rainfall, high altitude, hot sun, and sub-freezing temperatures.

Generally many thousands of known food plants are ignored by scientific researches and agriculturalists in modern crop production which are treated as a weed according to Ethno-Botanical Survey. C. album naturally grows as a weed in the field of winter season crops or Rabi crops (Wheat, Barley, Mustard, and others) in some places of India [7]. It has lower growth as a weed while cultivated crops are leafy and tall plants. The C. album is a significant food crop and valuable plant in Ayurveda in tropical and subtropical countries and is abundantly used as food and herbal medicine around the world $[2,5]$. The medicinal property of $C$. album is mainly found in its leaves and seeds. 


\section{Botanical Classification}

C. album L. is a leafy vegetable plant known as various names throughout the world. It is called 'Bathua sag' in Hindi and named as 'Pigweed' in English

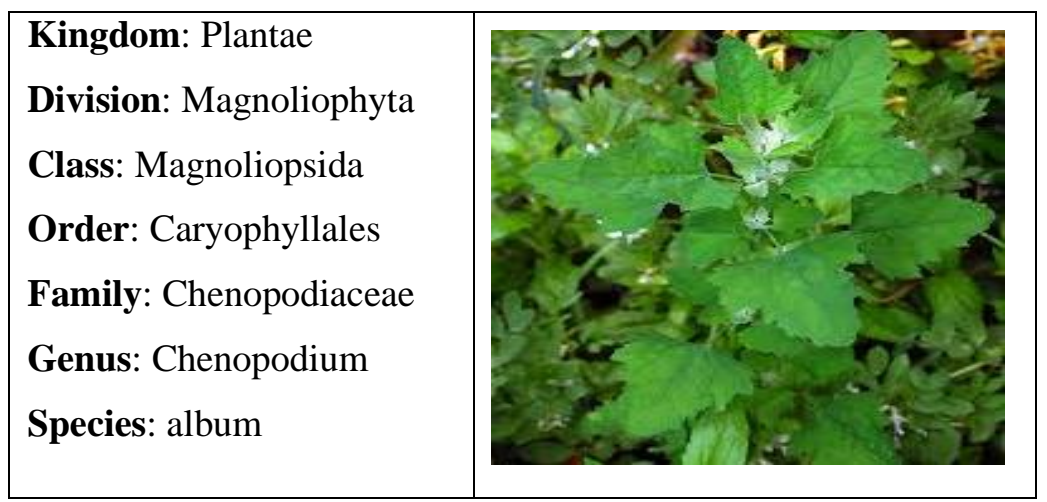

Figure 1. Botanical classification and whole plant of C. album [9].

and it is found all over the world [3]. This plant is a polymorphous, erect, greenish-white herb, up to $3.5 \mathrm{~m}$ in length, and grown at an altitude of 4,700 meters [8]. Common Name: Bathua (Hindi), Vastukah (Sanskrit), Fat Hen, Lamb's-quarters, Pigweed (English), Paruppukkirai (Tamil), Chandanbethu (Bengali), Bathua (Oriya), Kaduoma (Kannada), Pappukura (Telugu), Vastuccira (Malayalam), Chakvit (Konkani).

\section{Nutritional composition}

C. album is nutritional and healthy wild leafy vegetable cultivated in throughout the world [10-11]. Green leaves of $C$. album are very nutritious and rich in essential amino acid, calcium, Vitamin A and C [12]. On the other hand, another study evaluated that the $C$. album having a remarkable quantity of vitamin $\mathrm{C}$ and carotenoids in green leaves [13]. It is also a good source of fiber and iron content [14], that is higher as compared to spinach and cabbage, but lower than the amaranth leaves. Pande and Pathak [15] also reported that $C$. album is a good source of amino acids, leucine, isoleucine, lysine and vitamin $C$ (as an active component). C. album showed good tolerance to cold, drought and salinity stress. The other attractive feature of C. album is that it has high lysine content.

\section{Chemical constituents of $C$. album}

The whole plant of C. album has various phytochemicals like alkaloids, phenols, saponins, phytosterols, and flavonoids. It mainly has two flavonoids that are kaempferol and quercetin. The leaves of Chenopodium album are a potential source of essential oils and mineral matter mainly potash and a good amount of albuminoids. Its root contains saponin. The C. album extract has been used for the isolation of 1,2 and 16 apocarotenoids. The structure of new apocarotenoids determined to be (3R, 6R, 7E, 11E) 3-hydroxy-13 apo-alpha-carotene-13-one (1) and $(6 \mathrm{~S}, 7 \mathrm{E}, 9 \mathrm{E}, 11 \mathrm{E})-3$-oxo- 13apo-alpha-carotene-13-one (2) by the spectroscopic NMR and MS analysis [18].

\section{Medicinal properties of C. album}

Chenopodium album has some medicinal properties such as anthelmintic, antiphlogistic, antirheumatic, antidiarrheal, antioxidant, antimicrobial, contraceptive, laxative, odontalgic, etc. Chenopodium album isutilized for the treatment of rheumatism, bug bites, sunstroke, urinary problems, skin problems, etc. It is also known to have sedative and cooling properties, and leaves have been used to treat the burns [19]. 
Table 1. Physicochemical parameters

\begin{tabular}{|c|l|c|}
\hline S. No. & \multicolumn{1}{|c|}{ Nutrients } & Quantity \\
\hline 1. & Water & $84.3 \mathrm{~g}$ \\
\hline 2. & Energy & $44 \mathrm{Kcal}$ \\
\hline $\mathbf{3 .}$ & Carbohydrates & $7.3 \mathrm{~g}$ \\
\hline $\mathbf{4 .}$ & Fat & $0.8 \mathrm{~g}$ \\
\hline $\mathbf{5 .}$ & Protein & $4.3 \mathrm{~g}$ \\
\hline $\mathbf{6 .}$ & Fibre & $4 \mathrm{~g}$ \\
\hline $\mathbf{7 .}$ & \multicolumn{2}{|c|}{ Minerals } \\
\hline I & Iron & $1.2 \mathrm{mg}$ \\
\hline II & Calcium & $309 \mathrm{mg}$ \\
\hline III & Phosphorous & $72 \mathrm{mg}$ \\
\hline IV & Sodium & $43 \mathrm{mg}$ \\
\hline 8. & \multicolumn{2}{|c|}{} \\
\hline I & Vitamin A & $580 \mu \mathrm{g}$ \\
\hline II & Vitamin B Complex & \\
\hline (a) & Thiamine & $0.16 \mathrm{mg}$ \\
\hline (b) & Pantothenic acid & $0.092 \mathrm{mg}$ \\
\hline (c) & Riboflavin & $1.3 \mathrm{mg}$ \\
\hline (d) & Niacin & $90 \mathrm{mg}$ \\
\hline III & Vitamin C & \\
\hline & \multicolumn{2}{|c|}{} \\
\hline
\end{tabular}

Methanolic and aqueous leaf extracts of C. album showed the antilithiatic effects on experimentally induced urolithiasis in rats comparable to a standard antilithiatic agent, cystone [20].

\section{Antimicrobial properties}

Methanolic extract and ethyl acetate extract of $C$. album are used for the analysis of antimicrobial activity [21]. The antimicrobial activity is analyzed in the form of zone of inhibition of Staphylococcus aureus ATCC 25923 (17.3 mm), Bacillus subtilis UC 564 (19.7mm), Bacillus polymexia 474 (18.3mm), Streptococcus faecalis ATCC 29212 (16.7mm), Pseudomonas aerugenosa 25619 (17.7mm), Salmonella typhi $57(16.7 \mathrm{~mm})$, Vibrio cholerae $824(17.3 \mathrm{~mm})$ and Shigella dysenteriae ATCC C3 (17.3mm), Escherichia coli NCTC 8196 (18 mm), Penicillium notatum ATCC 11625 (15 mm), Aspergillus niger AB 41 (16.3), Candida albicans ATCC $18804(18.3 \mathrm{~mm})$ [21]. The antibacterial activity was determined by using the aqueous and methanolic extracts of C. album against pathogenic bacteria such as Escherichia coli, Salmonella typhimurium, Staphylococcus aureus, Proteus vulgaris and Pseudomonas aueruginosa [22]. The studies reported that the aqueous and methanolic extract of the $C$. album leaves was effective on the tested pathogens by using the paper disc diffusion method. While the aqueous extract has been found to have excellent antibacterial activity on Staphylococcus aureus, the methanolic leaf extract has been reported to have the strongest antibacterial activity against Pseudomonas aeruginosa [22-23].

Two antiviral proteins (AVPs) named CAP-I and CAP-II were used for the isolation from the $C$. album cv Pusa Bathua 1 leaf extract which is purified from the leaves and used to prevent the tobacco mosaic virus (TMV) and sunhemp rosette virus (SRV) infection on their respective host plants. They are different in the amino acid composition and N-terminal sequence. They also vary in IC50 values and the CAP-I had been shown to be 2.5 fold more effective than CAP-II in preventing the viral infection [24].

\section{Hepatoprotective activity}

Aqueous and alcoholic extracts of the Chenopodium album (aerial parts) showed hepato-protective activity. The aqueous extract (dose of $400 \mathrm{mg} / \mathrm{kg}$ ) reported to be more potent as compared to Silymarin. The 
alcoholic and aqueous extract of $C$. album $(200 \& 400 \mathrm{mg} / \mathrm{Kg}$ dose) has also been found to have significant hepatoprotective activity against paracetamol [25]. The study revealed such extracts restore the physiological integrity of hepatocytes. Both extracts (Aqueous and alcoholic) did not show any sign of toxicity up to the oral dose of $5 \mathrm{~g} / \mathrm{Kg}$ in mice $[25,26]$.

\section{Anthelmintic properties}

Chenopodium album Linn showed the anthelmintic activity against trichostrongylid nematodes of sheep by causing the mortality of worms and the prevention of egg hatching. Itwas revealed to have LC50 $=0.499$ $\mathrm{mg} / \mathrm{ml}$ in the egg hatch test. In vivo higher rate of reduction $(82.2 \%)$ in eggs per gram (EPG) of feces was revealed with Chenopodium album AME at $3.0 \mathrm{~g} / \mathrm{kg}$ on day 5 post-treatment [27]. Studies reported that $C$. album possess anthelmintic activity against cyathostomins, an important gastrointestinal nematode infecting equids.

\section{Benefits and losses of $C$. album}

\section{Used as a food}

C. album or Bathua is a winter season plant that is a popular green leafy vegetable and consumed as a food in India. It has medicinal properties and is very healthy and nutritious. The leaves of this plant are used in various dishes such as soups, curries, and paratha. C. album is employed to deal with numerous symptoms attributable to nutritional deficiencies. Many birds and animals like sparrow, chipmunks, and squirrels are eating their seeds and the plants are also used as fodder [19, 28].

\section{Health benefits}

Chenopodium fresh leaves have many beneficial medicinal properties. It is used to treat various diseases such as kidney stone, swelling, anemia, heart disease, jaundice and many more. C. album or Bathua leaves juice are used as a traditional medicine for intestinal parasites. It also improves the hemoglobin levels and is good for the heart. It is considered as a heart tonic and its leaves are good for liver, spleen and gall bladder [16]. C. album is used to treat muscular spasms and pain [29].

\section{Losses from C. album of agriculture}

C. album grows most vigorously in temperate and sub-temperate regions; however, it is also an important weed in almost all the winter or rabi crops of the tropics and subtropics. It is a most common weed in about 40 crops in almost 47 countries, mainly in cereals, sugarbeet, potatoes and corn. It is one of most common weeds of Canada and Europe, and in India, Mexico, New Zealand, Pakistan and South Africa is ranked amongst the six most serious weeds [30]. It is mostly grown in wheat, barley, chickpea, winter vegetables, horticultural gardens, maize, sunflower and soybean fields. Moreover, it is a

significant weed of tea and upland rice in Japan, citrus orchards and vineyards in Spain, cotton, soyabean and strawberries in the former Soviet Union, cotton, pastures and peanuts in the USA, rice in Mexico and tobacco in Canada [30]. In Europe and America, it is a problematic weed in maize, soybean, wheat, barley, potato and all vegetable crops.

C. album is responsible for the economic losses in agriculture all over the world except in the extreme desert climate [30]. It decreases the crop production by direct competition for light and nutrients. In field, important losses due to $C$. album have been recorded in many crops such as maize, soybeans, tomato, oat, barley, lucerne, and sugarbeet [31-32].

Seed contamination of crops by Chenopodium seeds not only affects the weed propagation, but also affects the seed quality and value of the crop. Seeds of $C$. album are very small and frequently contaminate the crop seeds during the harvesting of the weed infested fields [30].

C. album is also responsible for the indirect losses in agriculture as it is responsible for the disease transmission to main crop [33-34]. Several cultural, biological and chemical controls are available to check the $C$. album growth [35]. 


\section{Conclusion}

This review concluded that the Chenopodium album is nutritionally important plant that has many health benefits with various medicinal properties. It is mostly grown as a weed in India. As a leafy vegetable, it is the most significant plant for human health because of its higher nutrient content. Its leaves also contained several beneficial properties like antimicrobial, antioxidant, antidiarrheal etc which enhance its importance. Hence, it is utilized in the preparation of many healthy food products by the incorporation of C. album leaves extract and powder. It is highly beneficial for human health to cure many diseases and is used in folk medicines for treating various types of diseases from ancient times.

\section{Acknowledgements}

The authors are highly acknowledged their contributions of different researchers included in the text as references.

\section{Conflict of Interests}

The authors declare that there is no conflict of interests.

\section{References}

[1] J. Risi and N. W. Galwey and T. H. Coaker (1984). In Advances in applied biololgy. In: The Chenopodium grains of the andes: inca crops for modern agriculture. Academic, Landon, pp 145-216.

[2] A. A. Gohar and M. M. A. Elmazar (1997). Isolation of Hypotensive Flavonoids from Chenopodium species Growing Egypt. Phytother. Res., 11: 564-567.

[3] A. J. Patel, J. R. Patel, C. P. Macwan, M. A., Patel and A. K. Soni (2011). Pharmacognostical and proximate analysis of leaves of Borreriahispida. Asian J. Biochem. Pharm. Res., 2: 157-161.

[4] D. Jhade, P. M. Paarakh and U. Gavani (2009). Isolation of phytoconstituents from the leaves of Chenopodium album Linn. J. Pharma. Res., 2: 1192-1193.

[5] K. R. Kirtikar and B. D. Basu (1918). Indian medicinal plants Vol-3. Bishen Singh Mahendra Pal Singh and periodical experts.

[6] N. Yadav, N. Vasudeva, S. Singh and S. K. Sharma (2007). Medicinal properties of genus Chenopodium album Linn. Natural Product Radiance, 6: 131-134.

[7] S. K. Bhattacharjee (2001). Handbook of medicinal plants. Jaipur. Pointer Publishers, 1: 556-562.

[8] S. Kumar, S. Biswas, D. Mandal, H. N. Roy, S. Chakraborty and S. N. Kabir et al., (2007). Chenopodium album seed extract: A potent sperm-immobilizing agent both in vitro and in vivo. Contraception, 75: 7178.

[9] USDA, https://plants.usda.gov/java/ClassificationServlet?source=display\&classid=CHAL7

[10] J. B. Miller, K. W. James and P. M. A. Maggiore (1993). Tables of composition of Australian Aboriginal foods. Aboriginal Studies Press.

[11] T. P. A. Devasagayam, J. C. Tilak, K. K. Boloor, K. K. Sane, S. S. Ghaskadbi and R. D. Lele (2004). Review: Free radicals and antioxidants in human health: current status and future prospects. J. Assoc. Physicians India, 52: 794-804.

[12] A. D. Gonzalez, R. Janke and E. H. Rapoport (2003). Valor nutricional de las malezas comestibles. Ciencia Hoy, 13: 40-47.

[13] J. L. G. Guerrero and M. E. T. Isasa (1997). Nutritional composition of leaves of Chenopodium species (C. album L., C. murale L. and C. opulifolium Shraeder). Int. J. Food Sci. Nut., 48: 321-327.

[14] S. K. Yadav and S. Sehgal (2002). In vitro and In vivo availability of iron from Bathua (Chenopodium album) and Spinach (Spainacia oleracia) leaves. J. Food Sci. Technol., 39: 42-46.

[15] M. Pandey and A. Pathak (2010). Preliminary pharmacognostic evaluations and phytochemical studies on leaf of Chenopodium album (Bathua Sag). Asian J. Exp. Biol. Sci., 1: 91-95.

[16] Anupama (2015). Bathua (Chenopodium album) Health Benefits. https://www.bimbima.com/ayurveda/health-benefits-of-bathua-chenopodium-album/335/ 
[17] https://fdc.nal.usda.gov/fdc-app.html\#/food-details/169244/nutrients.

[18] M. M-Saric, I. Jasprica and A. Smolcic-Bubalo and Ana Mornar (2004). Optimization of chromatographic conditions in thin layer chromatography of flavonoids and phenolic acids. Croatica Chemica Acta, 77: 361-366.

[19] V. Choudhary (2020). Medicinal uses of Chenopodium album (Lambsquarters) Bathua. http://natureconservation.in/medicinal-uses-of-chenopodium-album-lambsquarters bathua/.

[20] I. Sikarwar, Y. N. Dey, M. M. Wanjari, A. Sharma, S. N. Gaidhani and A. D. Jadhav (2017). Chenopodium album Linn. leaves prevent ethylene glycol induced urolithiasis in rats. J. Ethnopharmacol, 195: 275-282.

[21] D. P. Nayak, P. K. Swain, O. P. Panda, P. Pattanaik and B. Srinivas (2010). Antimicrobial and Anthelmintic evalution of Chenopodium album. Int J Pharma World Res., 4: 201-215.

[22] K. P. Singh, A. K. Dwevedi and G. Dhakre (2011). Evaluation of antibacterial activities of Chenopodium album L., Int. J. Applied Biolo. Pharm. Technol., 2: 398-401.

[23] L. Amjad and Z. Alizad (2012). Antibacterial Activity of the Chenopodium album Leaves and Flowers Extract. World Acad. Sci., Eng. Technol., 61: 903-906.

[24] S. Dutt, S. Narwal, H. C. Kapoor and M. L. Lodha (2003). Isolation and Characterization of two protein isoforms with antiviral activity from Chenopodium album leaves. J. Plant Biochem. Biot., 12: 117-122.

[25] A. Pal, B. Banerjee, T. Banerjee, M. Masih and K. Pal (2011). Hepatoprotective activity of Chenopodium album linn. plant against paracetamol induced hepatic injury in rats. Int. J. Pharm. Sci., 3: 55-57.

[26] V. Nigam and P. M. Paarakh (2011). Hepatoprotective activity of Chenopodium album linn. against paracetamol induced liver damage. Pharmacologyonline, 3: 312-328.

[27] A. Jabbar, M. A. Zaman, Z. Iqbal, M. Yaseen and A. Shamim (2007). Anthelmintic activity of Chenopodium album L. against trichostrongylid nemotodes of sheep. J. Ethanopharmacol., 114: 86-91.

[28] A. Bhargava, S. Shukla and D. Ohri (2003). Relative selection efficiency for foliage yield and quality characters in vegetable Chenopodium over different cuttings. J. Appl. Hort., 5: 85-86.

[29] A. Poonia and A. Upadhayay (2015). Chenopodium album Linn: review of nutritive value and biological properties. J. Food Sci. Technol., 52: 3977-3985.

[30] L. G. Holm, D. L. Plucknett, J. V. Pancho and J. P. Herberger (1977). The World's Worst Weeds. Distribution and Biology. Honolulu, Hawaii, USA: University Press of Hawaii.

[31] K. P. Sibuga and J. D. Bandeen (1980). Effects of green foxtail and lamb's-quarters interference in field corn. Can. J. Plant Sci., 60: 1419-1425.

[32] M. Ngouajio, C. Lemieux and G. D. Leroux (1999). Prediction of corn (Zea mays) yield loss from early observations of the relative leaf area and the relative leaf cover of weeds. Weed Science, 47: 297-304.

[33] A. Sharma, R. Ram and A. A. Zaidi (1998). Rubus ellipticus, a perennial weed host of Prunus necrotic ring spot virus in India. Plant Disease, 82: 1283.

[34] D. Ksiazek (1976). The spread of potato viruses and the chemical control of colorado beetle. Zesz. Probl. Postepow Nauk Roln., 174: 127-143.

[35] https://www.cabi.org/isc/datasheet/12648\#topreventionAndControl 